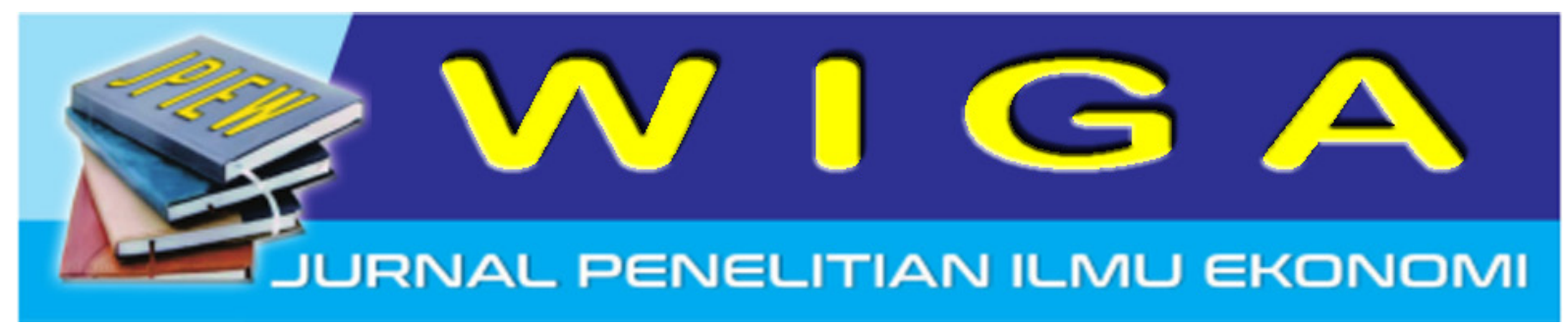

\title{
PENGARUH CORPORATE SOCIAL RESPONSIBILITY TERHADAP KINERJA KEUANGAN
}

\author{
Riswan Ludfi, Iqbal Firdausi \\ riswanludfi@stiei-kayutangi-bjm.ac.id. \\ iqbalfirdausi@stiei-kayutangi-bjm.ac.id
}

\begin{abstract}
Abstrak: Tujuan dari penelitian ini adalah untuk mengetahui, Pengaruh variabel CSR (karyawan, lingkungan, masyarakat) sebagai varables independen baik secara parsial maupun secara simultan terhadap Return on Asset, Pengaruh variabel CSR (karyawan, lingkungan, masyarakat) sebagai varables independen baik secara parsial atau secara simultan terhadap Q. Tobin metode penelitian ini adalah analisis regresi linier berganda. Sampel penelitian diambil dari data Perusahaan ini di BEI melalui laporan tahunan dan informasi keuangan dari laporan keuangan bagi produsen, pengembang, dan penambang (hanya korporat perdagangan biasanya murni tidak dimasukkan) dalam periode 20102012 dengan metode purposive sampling. Ada 95 perusahaan yang memenuhi kriteria dan akumulasi selama tiga tahun, sehingga total sampel menjadi 285 sampel.

Hasil penelitian menunjukkan bahwa semua variabel CSR memberikan pengaruh yang signifikan positif secara simultan terhadap variabel dependen ROA dan Tobin Q. Secara parsial, variabel karyawan dan masyarakat yang positif signifikan mempengaruhi variabel dependen ROA, dan hanya karyawan sebagai variabel independen memiliki pengaruh positif terhadap Tobin Q
\end{abstract}

\section{Kata kunci: CSR, Return Of Assets, Tobin Q}

Abstrac:The aims of this research were to know: (1) The influence of CSR variables (employee, environment, community) as independent varables either partially or simultaneously towards Return on Assets (2) The influence of CSR variables(employee, environment, community) as independent varables either partially or simultaneously towards Tobin's $Q$. The method of this research is multiple linear regression analysis. The research sample were taken from Corporate's data on IDX through annual report and financial information from financial reports for manufacturers, developers, and miners (just typically pure trading corporates were not included) in the period 2010 to 2012 with the purposive sampling method. There were 95 of the companies that met the criteria and were accumulated for three years, so total of samples became 285 samples.

The result of research showed that all of CSR variables gave positive significant influence simultaneously towards the dependent variables of ROA and Tobin's Q. Partially, the variables of employees and community were positively significant influencing the dependent variable of ROA, and only employees as the independent variable had positive influence towards Tobin's $Q$

Keywords : CSR, Return Of Assets, Tobin's $Q$ 


\section{PENDAHULUAN}

\section{Latar Belakang Masalah}

Perkembangan ilmu pengetahuan dan teknologi dua puluh tahun terakhir membawa dampak pada kemajuan pertumbuhan bisnis dan industri. Kemajuan tersebut berperan mengubah dua kondisi, yaitu positif (positive externalities) dan negatif (negative externalities). Hadi (2011: 36-37) menyatakan Positive externalities adalah bahwa perusahaan memberi manfaat peningkatan ekonomi, sosial dan lingkungan dalam bentuk peningkatan kesejahteraan, infrastruktur, tata sosial, ilmu pengetahuan dan teknologi, sedangkan negative externalities, keberadaan perusahaan memunculkan ketimpangan sosial, diskriminasi, relokasi masyarakat kecil termarginal akibat digunakan untuk kawasan industri, sebagian masyarakat kehilangan tempat kerja akibat relokasi, polusi pencemaran lingkungan, global warming dan sejenisnya.

Beberapa penelitian menyebutkan setidaknya ada dua kelemahan implementasi CSR. Rachman, Effendi, dan Wicaksana (2011: 4) mengungkapkan kelemahan implementasi CSR yaitu pertama, perusahaan melaksanakan CSR dengan program yang sangat beragam dan didorong atas permintaan masyarakat, yang seharusnya program CSR dirancang terkait dengan strategi bisnis perusahaan. Konsekuensinya, CSR menjadi biaya yang dianggarkan oleh manajemen perusahaan. Kedua, umumnya CSR yang dilakukan tidak tuntas, tidak dapat menyelesaikan masalah bahkan CSR memperbesar ketergantungan masyarakat kepada perusahaan.

Penelitian Titisari, Eko dan Doddy (2010) membahas CSR dengan kinerja perusahaan serta terkait dengan penelitian terdahulu milik Fiori et al (2007), dimana penelitian ini menguji informasi CSR, yang menggunakan parameter employment, environment, dan community, serta pengaruhnya terhadap informasi keuangan dan harga saham. Penelitian ini menunjukkan environmental performance berpengaruh positif terhadap economic performance. Pengaruh negatif CSR lainnya ditunjukkan penelitian Sayekti dan
Windabio (2007) terhadap earning response coefficient serta mengindikasikan bahwa investor mengapresiasi informasi CSR yang diungkapkan dalam laporan tahunan perusahaan.

Terdapat tiga variabel, yaitu employee, environment, community, dimana ketiga parameter ini merupakan variabel-variabel yang paling sering disinggung karena makna universalnya, hanya saja seringkali perusahaan memiliki istilah yang berbeda dalam penyebutannya. Penelitian ini menguji kembali pengaruh employee, environment, dan community terhadap kinerja keuangan perusahaan. Kinerja keuangan dinilai menggunakan analisis rasio profitabilitas yakni ROA (Return on Assets). Berbeda dengan penelitian terdahulu, dalam penelitian ini juga menggunakan Tobin's $\mathrm{Q}$ ratio untuk mewakili nilai perusahaan selain ROA. Tobin's Q ratio digunakan dalam menilai nilai perusahaan karena dapat menunjukkan estimasi pasar keuangan dengan tingkat pengembaliannya serta memperhatikan sisi internal dan eksternal dari perusahaan yang diteliti. Perbedaan lainnya, penelitian ini menyesuaikan kombinasi susunan indikator GRI ver. 3.1 yang terdiri dari tiga indikator utama economy, environment, dan social menjadi environment, employee, dan community. Pengambilan nilai parameter tetap menggunakan content analysis yaitu pengambilan info mengenai komponenkomponen parameter GRI versi 3.1 melalui Laporan Tahunan yang diterbitkan setiap perusahaan.

\section{Rumusan Masalah}

Berdasarkan uraian yang telah dikemukakan pada latar belakang masalah diatas, maka permasalahan yang akan dibahas dapat dirumuskan sebagai upaya peningkatan pemahaman tentang hal berikut:

a. Apakah penerapan CSR (Employee, Environment, Community) berpengaruh terhadap Return of Assets?

b. Apakah penerapan CSR (Employee, Environment, Community) berpengaruh terhadap Tobin's $Q$ ? 


\section{Tujuan Penelitian}

Secara umum penelitian ini dimaksudkan untuk menganalisis variabel-variabel CSR yang mempengaruhi kinerja keuangan perusahaan dalam rangka strategi peningkatan usaha. Secara khusus dan lebih rinci penelitian ini bertujuan untuk:

1. Untuk menganalisis pengaruh penerapan CSR (Employee, Environment, dan Community) terhadap Return of Asset.

2. Untuk menganalisis pengaruh penerapan CSR (Employee, Environment, dan Community) terhadap Tobin's $Q$

\section{Kajian Teori \\ Etika Bisnis}

Etika merupakan semacam penelaahan baik aktivitas penelaahan maupun hasil-hasil penelaahan itu sendiri - sedangkan moralitas merupakan subjek (Velasques 2002 hal. 7). Pemahaman etika jika dialokasikan kepada bisnis, akan membentuk pengertian yang disebut Etika Bisnis. Etika bisnis menurut Velasquez (2002: 12) merupakan studi yang dikhususkan mengenai moral yang benar dan salah. Institusi yang paling berpengaruh di dalam masyarakat sekarang ini adalah intitusi ekonomi, yaitu perusahaan bisnis yang memproduksi barang dan jasa.

\section{Pengertian dan Konsep Corporate Social Responsibility (CSR)}

CSR sendiri memiliki beragam definisi. Menurut Rachman et al (2011: 16) menyatakan bahwa CSR adalah suatu tindakan atau konsep yang dilakukan oleh perusahaan (sesuai kemampuan perusahaan tersebut) sebagai bentuk tanggung jawab mereka terhadap sosial/lingkungan sekitar perusahaan berada.

Titisari et al (2010) membagi CSR menjadi tiga parameter, yaitu: environtment, employment, dan community. Parameter ini berdasarkan pada Brammer, Brook, dan Pavelin (2005). Begitu pula Fiori et al ((2007), juga menetapkan ketiga parameter tersebut berdasarkan konsep parameter Brammer. Penelitian Brammer et al (2005) secara terperinci menjelaskan kembali subkatagori dari ketiga parameter tersebut, yaitu: (1) Environmental performance; (2) Employee performance; (3) Community performance (kinerja komunitas).

Menurut Brammer et al (2005) indikator employee berdasarkan enam ukuran, yaitu: (1) Health and safety system; (2) Systems for employee training and development; (3) Equal opportunities policies; (4) Equal opportunity systems; (5) System for good employee relations ; (6) System for job creation and security.

Konsep lingkungan menurut Rachman et al (2001: 64) dalam kaitan operasional perusahaan/organisasi dengan lingkungannya maka terdapat usaha-usaha perusahaan/organisasi untuk meminimalisasi dampak-dampak negatif yang terjadi di lingkungan. Bentuk usaha-usaha tersebut antara lain: (1) Sustainable consumption; (2) Climate change mitigation and adaption; (3) Protection and restoration of the natural environment.

Variabel ketiga adalah komunitas, definisi komunitas menurut Kartajaya (2008: 161), komunitas adalah sekelompok orang yang saling peduli satu sama lain lebih dari yang seharusnya, di mana dalam sebuah komunitas terjadi relasi pribadi yang erat antar para anggota komunitas tersebut karena adanya kesamaan interest dan values.

CSR (environment, employee, community) dan Kinerja Keuangan

Terdapat dua ukuran kinerja keuangan yang digunakan dalam penelitian ini, yaitu: Return on Asset merupakan rasio yang menunjukkan hasil (return) atas jumlah aktiva yang digunakan dalam perusahaan atas suatu ukuran tentang aktivitas manajemen (Kasmir 2008 hal. 201). Ukuran kedua adalah Tobin's $Q$ digunakan untuk mengukur kinerja eksternal perusahaan, berbeda dengan ROA yang digunakan untuk mengukur kinerja operasional perusahaan. Hubungan antara faktor lingkungan (environment) dengan kinerja keuangan berdasarkan prinsip profitabilitas, kontinuitas perusahaan hingga pertumbuhan perusahaan adalah dengan menarik hubungan kepedulian perusahaan terhadap lingkungan dan pengaruhnya terhadap ukuran-ukuran kinerja 
keuangan. Selanjutnya penelitian employee yang ditunjukkan Brine et al (2007) menyatakan bahwa penerapan CSR mendorong perusahaan untuk merekrut karyawan yang berbakat dan bermacam-macam dorongan pekerjaan. Variabel ketiga, yaitu komunitas, diyakini memiliki keterkaitan tertentu dengan kinerja keuangan.

\section{METODE PENELITIAN}

\section{Jenis Penelitian}

Jenis penelitian ini secara umum adalah penelitian kausalitas, yaitu penelitian yang dilakukan dengan penjelasan hubungan sebab akibat terhadap objek yang diteliti pada Bursa Efek Indonesia. Penelitian ini menggunakan pendekatan kuantitatif melalui pengujian hipotesis antara variabel independen dan dependen.

\section{Populasi, Sampel dan Teknik Sampling}

Populasi penelitian ini adalah perusahaanperusahaan yang berkecimpung dalam industri manufaktur yang tercatat dalam Bursa Efek Indonesia yang mempublikasikan laporan keuangan tahunan selama tiga tahun, yaitu 20102012. Pengambilan sampel dalam penelitian ini menggunakan Purposive sampling. Sampel pada penelitian ini diambil dengan kriteria-kriteria sebagai berikut:

1. Perusahaan-perusahaan manufaktur, pengembangan, pertambangan (bukan perdagangan semata) yang terdaftar dalam Bursa Efek Indonesia sejak tahun 20102012.

2. Perusahaan-perusahaan manufaktur yang sudah melaksanakan good corporate governance dengan menerbitkan laporan tahunan atau annual report.

3. Perusahaan-perusahaan manufaktur, pengembangan, pertambangan, (perdagangan murni dikecualikan) yang sudah menerbitkan laporan keuangan untuk periode yang berakhir 31 Desember selama periode 2010-2012.

Berdasarkan kriteria-kriteria yang disebutkan diatas, jumlah populasi sebanyak 107 perusahaan kemudian dikurangi jumlah perusahaan yang tidak memenuhi kriteria pengambilan sampel karena tidak memiliki Annual Report sebanyak 4 perusahaan maka didapatkan sebanyak 95 perusahaan yang layak dijadikan sebagai sampel.

\section{Variabel Penelitian}

Variabel penelitian ini terdiri dari Environment (X1), Employee (X2), Community (X3) yang merupakan variabel independen sebagai pembentuk CSR. Variabel independen akan menentukan variabel kinerja keuangan yang terdiri dari variabel Return of Aset (Y1) dan variabel Tobin's $Q$ (Y2) sebagai terikat (dependen).

\section{Metode dan Prosedur Pengumpulan}

\section{Data}

Metode pengumpulan data yang digunakan adalah data sekunder serta dokumentasi, yaitu laporan keuangan dan laporan tahunan dan laporan tahunan selama tiga tahun buku dari sampel perusahaan yang akan diteliti yang tercatat dakam Bursa Efek Indonesia periode 2010-2012.

\section{Analisis Data}

Metode analisis pada penelitian ini menggunakan analisis regresi linear berganda. Model matematis yang digunkan dapat dirumuskan sebagai berikut:

$\mathrm{Y}_{1}=\mathrm{b}_{0}+\mathrm{b}_{1} \mathrm{X}_{1}+\mathrm{b}_{2} \mathrm{X}_{2}+\mathrm{b}_{3} \mathrm{X}_{3}+\mathrm{e}$

$\mathrm{Y}_{2}=\mathrm{b}_{0}+\mathrm{b}_{1} \mathrm{X}_{1}+\mathrm{b}_{2} \mathrm{X}_{2}+\mathrm{b}_{3} \mathrm{X}_{3}+\mathrm{e}$

Keterangan

$\mathrm{Y}_{1}$

$\mathrm{Y}_{2}$

$=$ Return on Asset (ROA)

$\mathrm{b}_{0}$

$=$ Tobin's $Q$

$=$ Konstanta

$\mathrm{b}_{1}, \mathrm{~b}_{2}, \mathrm{~b}_{3} \quad=$ Koefisien Regresi

$\mathrm{X}_{1}$

= Environment

=Employee

$\mathrm{X}_{2}$

= Community

= Error term

\section{Pengujian Hipotesis}

$\mathrm{R}^{2}$ digunakan untuk menentukan seberapa besar variasi variabel dependen $(\mathrm{Y})$ yang dapat dijelaskan oleh variabel dependen (X) dimana $0 \leq \mathrm{R}^{2} \leq 1$. Uji $\mathrm{F}$ digunakan untuk 
menguji variabel bebas $(\mathrm{X})$ terhadap variabel terikat (Y) secara simultan. Tingkat kepercayaan yang digunakan adalah $95 \%$ atau tingkat kesalahan $(\alpha)$ sebesar 5\% dengan derajat kebebasan $(\mathrm{df})=(\mathrm{n}-\mathrm{k})(\mathrm{k}-\mathrm{i}=1)$. Ketentuan, jika $\mathrm{F}_{\text {hitung }}>\mathrm{F}_{\text {tabel }}$, maka $\mathrm{H}_{1}$ diterima dan sebaliknya jika $\mathrm{F}_{\text {hitung }}<\mathrm{F}_{\text {tabel }}$ maka $\mathrm{H}_{1}$ ditolak. Uji $\mathrm{t}$ digunakan untuk menguji pengaruh variabelvariabel bebas $(\mathrm{X})$ terhadap variabel terikat $(\mathrm{Y})$ secara parsial atau pada dasarnya menunjukkan seberapa jauh pengaruh satu variabel bebas secara individual dalam menerangkan variasi variabel terikat.

\section{HASIL PENELITIAN DAN PEMBAHASAN}

\section{Gambaran Umum Penelitian}

Objek penelitian ini meliputi 95 perusahaan yang terdaftar di Bursa Efek Indonesia selama periode 2010-2012. Sebagian besar perusahaan dalam penelitian ini berkaitan dengan pertambangan, manufaktur, dan pengembangan karena memiliki permasalahan yang erat dengan hasil produk yang berkaitan erat dengan lingkungan. Perusahaan murni perdagangan dan jasa dikecualikan dalam pengambilan sampel penelitian terkecuali apabila terdapat perusahaan afiliasasi yang bergerak di bidang manufaktur, pertambangan dan pengembangan.

Metode Purposive Sampling digunakan dalam pengambilan sampel dalam pengumpulan data, yaitu dengan metode dengan pengambilan sampel yang dilakukan sesuai dengan tujuan penelitian yang ditetapkan.

Tabel 1. Jumlah Kelompok Perusahaan Dalam Industri Pertambangan, Manufaktur Dan Pengembangan (tidak hanya distribusi saja) 2010-2012

\begin{tabular}{clc}
\hline 6 & Consumer Good Industry & 16 \\
\hline 7 & $\begin{array}{l}\text { Infrastructure, Utilities, and } \\
\text { Transportation }\end{array}$ & 5 \\
\hline 8 & $\begin{array}{l}\text { Property, Real Estate, And Building } \\
\text { Construction }\end{array}$ & 7 \\
\hline 9 & Animal Feed $\quad$ Jumlah & 1 \\
\hline \multicolumn{1}{c}{$\mathbf{9 5}$} \\
\hline
\end{tabular}

Sumber : Data Sekunder Diolah, 2015

Hasil Analisis Deskripif Data

Tabel.2 Deskripsi Variabel Penelitian

\begin{tabular}{|l|l|c|c|c|c|}
\hline & & Mini & Maximu & & \\
& $\mathrm{N}$ & mum & $\mathrm{m}$ & Mean & Std. Deviation \\
\hline
\end{tabular}

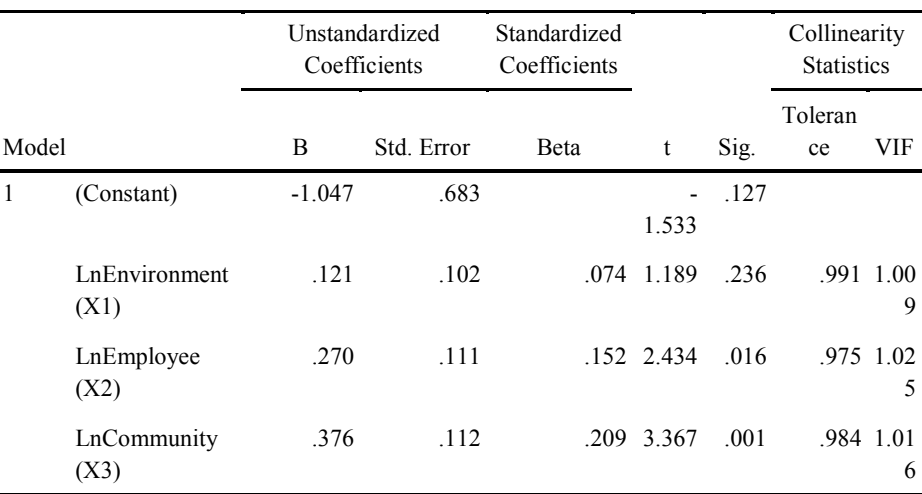

\begin{tabular}{|l|c|c|c|c|c|}
\hline $\mathrm{X} 1$ & 285 & 1.20 & 100.00 & 52.4436 & 27.55884 \\
\hline $\mathrm{X} 2$ & 285 & 2.05 & 100.00 & 62.4046 & 28.43337 \\
\hline $\mathrm{X} 3$ & 285 & 1.27 & 100.00 & 61.0753 & 27.53276 \\
\hline $\mathrm{Y} 1$ & 285 & -75.58 & 97.56 & 8.4331 & 15.69296 \\
\hline $\mathrm{Y} 2$ & 285 & -.51 & 20.94 & 2.0653 & 2.93430 \\
\hline $\begin{array}{l}\text { Valid } \\
\mathrm{N} \\
\text { (listwis } \\
\text { e) }\end{array}$ & 285 & & & & \\
\hline $\begin{array}{l}\text { X1 = environment, X2 = employee, X3 = community, Y1 } \\
\text { ROA, Y2 = Tobin's Q }\end{array}$ & & & \\
\hline
\end{tabular}

${ }^{1}$ Data dalam bentuk presentase kecuali varabel

Tobin's $Q$ (Y2)

Sumber: Data Sekunder diolah, 2015

Dari pengujian deskriptif statistik yang tersaji pada Tabel 2 menunjukkan nilai perusahaan yang diukur dengan ROA dan Tobins $Q$. Dari analisis statistik deskriptif diketahui nilai

\begin{tabular}{clrl}
\hline No & Sektor Industri & Jumlahrata-rata ROA sebesar $8,4331 \%$ dengan nilai \\
\hline 1 & Mining & 19 & standar deviasi $15,6929 \%$ berarti variasi data \\
\hline 2 & Trade, Service, Investment & 8 & lebih besar dari rata-rata. Tobins $Q$ memiliki rata- \\
\hline 3 & Agriculture & 9 & rata sebesar 2,065 dengan nilai standar deviasi \\
\hline 4 & Miscellaneous Industry & 14 & sebesar 2,934, yang berarti rata lebih dari satu,
\end{tabular}


maka nilai pasar perusahaan rata-rata lebih besar dari nilai asset perusahaan yang tercatat.

\section{Analisis Regresi}

Melalui hasil uji asumsi klasik diketahui data dalam penelitian ini terdistribusi dengan normal dan tidak terdapat ketidaknormalan, heteroskedastisitas, multikolienaritas, dan autokorelasi. Data yang tersedia telah memenuhi syarat untuk menggunakan model regresi linier berganda. Model analisis regresi berganda penelitian ini adalah:

Regresi linier berganda untuk variabel ini:

Tabel 3. Hasil Analisis Regresi Berganda ROA Sumber : Data Sekunder Diolah, 2015

Regresi linier berganda pada variabel dependent Tobin's $Q$ ditunjukkan pada tabel dibawah :

Tabel 4. Hasil Analisis Berganda Tobin's $Q$ dependent ROA dapat dilihat pada tabel berikut

secara parsial tidak berpengaruh signifikan terhadap $\mathrm{Y}_{2}$.

c. Koefisien $\mathrm{X}_{2}\left(\mathrm{~b}_{2}\right)=0,243$ menunjukkan bahwa employee $\left(\mathrm{X}_{2}\right)$ berpengaruh positif terhadap Tobin's $Q\left(\mathrm{Y}_{2}\right)$. Hal ini berarti bahwa jika variabel employee ditingkatkan 5,9\% (R-Square pada tabel determinasi Tobin's Q), maka akan menaikkan Tobin's $Q$ sebesar 0,243.

d. Koefisien $\mathrm{X}_{3}\left(\mathrm{~b}_{3}\right)=0,098$, namun tingkat signifikan 0,282 (diatas 0,05), Hal ini berarti bahwa jika variabel community secara parsial tidak berpengaruh signifikan terhadap $\mathrm{Y}_{2}$.

\section{Uji Hipotesis}

\section{Hasil Uji Regresi Simultan (Uji F)}

Tabel 5. Hasil Uji F Variabel Dependen ROA

\begin{tabular}{llrrrrr}
\hline \multicolumn{2}{l}{ Model } & $\begin{array}{c}\text { Sum of } \\
\text { Squares }\end{array}$ & Df & $\begin{array}{c}\text { Mean } \\
\text { Square }\end{array}$ & F & Sig. \\
\hline 1 & $\begin{array}{l}\text { Regressio } \\
\mathrm{n}\end{array}$ & 27.044 & 3 & 9.015 & 7.269 & $.000^{\mathrm{a}}$ \\
& & & & & & \\
& Residual & 300.095 & 281 & 1.240 & & \\
& Total & 327.129 & 284 & & & \\
\hline
\end{tabular}

\begin{tabular}{|c|c|c|c|c|c|c|}
\hline \multirow[b]{2}{*}{ Mode } & & \multicolumn{2}{|c|}{$\begin{array}{l}\text { Unstandardized } \\
\text { Coefficients }\end{array}$} & \multirow{2}{*}{$\frac{\begin{array}{c}\text { Standardized } \\
\text { Coefficients }\end{array}}{\text { Beta }}$} & \multirow[b]{2}{*}{$\mathrm{t}$} & \multirow[b]{2}{*}{ Sig. } \\
\hline & & B & Std. Error & & & \\
\hline \multirow[t]{4}{*}{1} & (Constant) & -1.743 & .540 & & -3.227 & .001 \\
\hline & $\begin{array}{l}\text { LnEnvironment } \\
\text { (X1) }\end{array}$ & .161 & .085 & .122 & 1.890 & .060 \\
\hline & $\begin{array}{l}\text { LnEmployee } \\
\text { (X2) }\end{array}$ & .243 & .091 & .163 & 1.667 & .008 \\
\hline & $\begin{array}{l}\text { LnCommunity } \\
\text { (X3) }\end{array}$ & .098 & .091 & .065 & 1.077 & .282 \\
\hline
\end{tabular}

Sumber : Data Sekunder Diolah, 2015

Berdasarkan hasil pengolahan data pada tabel 4 diperoleh model persamaan regresi sederhana sebagai berikut:

$\mathrm{Y}_{2}=-1,743+0,161$ Environment $+0,243$

Employee $+0,098$ Community

a. Konstanta sebesar -1,743 menyatakan bahwa jika nilai variabel independen $\left(\mathrm{X}_{1}, \mathrm{X}_{2}, \mathrm{X}_{3}\right)=0$, maka konstanta Tobin' $\mathrm{Q}$ akan sebesar $-1,743$.

b. Koefisien $\mathrm{X}_{1}\left(\mathrm{~b}_{1}\right)=0,161$, namun tingkat signifikan 0,060 (diatas 0,05), Hal ini berarti bahwa jika variabel environment a. Predictors: (Constant), LnEnvironment, LnEmployee, LnCommunity

b. Dependent Variable: LnROA

Skmplerer : Data Sekunder Diolah, 2015

.9331 .072 Pada Tabel 5 diatas tampak bahwa nilai F hitung sebesar 14,367 dan signifikansi sebesar 0,000 . Apabila dibandingkan dengan $\mathrm{F}$ tabel yang nilainya 2,41 pada tabel, maka Fhitung $>$ Ftabel $(7,269>2,40)$ dan tingkat signifikansi 0,000 lebih kecil daripada 0,05 . Hal ini berarti bahwa Ho ditolak dan Ha diterima, maka variabelvariabel CSR berpengaruh secara simultan

Tabel 6. Hasil Uji F Variabel Dependen Tobin's Q

\begin{tabular}{lrrrrrr}
\hline \multirow{2}{*}{ Model } & $\begin{array}{l}\text { Sum of } \\
\text { Squares }\end{array}$ & Df & Square & F & Sig. \\
\hline 1 & Regression & 14.450 & 3 & 4.817 & 4.941 & $.002^{\mathrm{a}}$ \\
& Residual & 266.145 & 273 & .975 & & \\
\hline
\end{tabular}
terhadap ROA. 
Total

$280.596 \quad 284$

a. Predictors: (Constant), LnEnvironment, LnEmployee, LnCommunity

b. Dependent Variable: LnTobin

Sumber : Data Sekunder Diolah, 2015

Pada tabel 6 diatas tampak bahwa nilai $\mathrm{F}$ hitung sebesar 4,941 dan signifikansi sebesar 0,002. Apabila dibandingkan dengan $\mathrm{F}$ tabel yang nilainya 2,41 pada tabel, maka Fhitung $>$ Ftabel $(4,941>2,40)$ dan tingkat signifikansi 0,002 lebih kecil daripada 0,05 . Hal ini berarti bahwa Ho ditolak dan variabel-variabel CSR secara simultan berpengaruh signifikan terhadap Tobin's $Q$.

\section{Hasil Uji Regresi Parsial (Uji t)}

Uji $t$ pada Tabel 3 dilakukan untuk melihat bagaimanakah pengaruh environment terhadap ROA secara parsial. Hasil regresi pada Tabel 3 menunjukkan nilai thitung sebesar 1,189 dan signifikansi sebesar 0,236 (nilai t-tabel penelitian ini sebesar 1,9719). Perbandingan pada koefisien konstanta ternyata nilai t hitung lebih kecil daripada $t$ tabel $(1,189<1,9719)$ dan signifikansi lebih besar dari 0,05 . Berarti dengan demikian menerima $\mathrm{H}_{0}$ yang berarti variabel environment secara parsial tidak berpengaruh secara signifikan terhadap RoA. Variabel employee menunjukkan nilai $\mathrm{t}$ hitung sebesar 2,434 dan signifikansi 0,016, Perbandingan pada koefisien konstanta ternyata nilai t hitung lebih besar daripada $t$ tabel $(2,434>1,9719)$ dan nilai signifikansi lebih kecil daripada 0,05 $(0,016<$ $0,05)$ berarti variabel employee secara parsial berpengaruh signifikan terhadap ROA. Hasil regresi community menunjukkan nilai t hitung sebesar 3,367 dan signifikansi sebesar 0,001. Perbandingan pada koefisien konstanta ternyata nilai thitung lebih besar daripada $t$ tabel $(3,367>$ 1,9719) dan nilai signifikansi lebih kecil daripada $0,05(0,001<0,05)$, maka disimpulkan menolak $\mathrm{H}_{0}$ yang berarti variabel community secara parsial berpengaruh terhadap ROA.

Hasil regresi pada Tabel.4 menunjukkan nilai t hitung environment sebesar 1.890 dan signifikansi sebesar 0,060 , dengan nilai $\mathrm{t}$ tabel sebesar 1,9719, maka disimpulkan menerima Ho yang berarti variabel environment secara parsial tidak berpengaruh terhadap Tobin's $Q$. Perbandingan pada koefisien konstanta employee ternyata nilai $t$ hitung lebih besar daripada $t$ tabel, maka disimpulkan menolak Ho yang berarti variabel employee secara parsial berpengaruh terhadap Tobin's $Q$. Nilai positif menandakan nilai variabel searah dengan Tobin's $Q$ yang artinya bernilai positif. Nilai t hitung community sebesar 1,077 dan signifikansi 0,282. Tabel tersebut menunjukkan nilai t hitung lebih kecil daripada $t$ tabel dan nilai signifikansi lebih besar daripada 0,05 maka disimpulkan menerima Ho yang berarti variabel community secara parsial tidak berpengaruh terhadap Tobin's $Q$.

\section{Pengaruh CSR (environment,} employee, community) Terhadap Return on Asset (ROA).

Variabel-variabel CSR berpengaruh secara stimultan terhadap Return on Asset . Secara parsial, uji model regresi pertama menunjukkan variabel employee dan community memiliki pengaruh positif dan hanya variabel environment yang tidak berpengaruh terhadap Return on Asset. Pengaruh stimultan CSR dalam penelitian ini sejalan dengan Fauzi et al (2009), Cooper et al (2009) dan biscaccianti (2003), bahwa CSR secara stimultan berpengaruh terhadap kinerja keuangan perusahaan. Pelaksanaan CSR untuk variabel environment tidak memiliki pengaruh terhadap Return on Asset. Hal ini menunjukkan kurangnya perhatian perusahaan-perusahaan pada faktor lingkungan untuk dijadikan keputusan tingkat pengembalian. Faktor lingkungan tentu membutuhkan tambahan biaya yang akan mempengaruhi hasil penyampaian laporan keuangan suatu perusahaan yang secara otomatis mempengaruhi presentase jumlah nilai Return on Asset. Faktor ini berbeda dengan employee yang berkaitan dengan internal perusahaan dan community yang berkaitan dengan image perusahaan. Sinergi antara ketiga variabel akan mempengaruhi nilai perusahaan terhadap masyarakat, dalam hal ini merupakan bagian dari community, yang artinya akan meningkatkan kepercayaan terhadap produk perusahaan dan tidak menutup kemungkinan 
meningkatkan profitabilitas perusahaan. Sesuai dengan Brine et. al (2007) dimana CSR meningkatkan penjualan dan ekuitas perusahaan dan peningkatan tersebut akan mempengaruhi ROA perusahaan.

\section{Pengaruh CSR (environment, employee, community) Terhadap Tobin's $Q$}

Berdasarkan penelitian CSR berpengaruh signifikan secara stimultan terhadap Tobin's $Q$. Artinya, ada pengaruh CSR terhadap peluang investasi atau kondisi pertumbuhan saham perusahaan. Terdapat pengaruh positif employee terhadap Tobin's $Q$, namun untuk variabel environment dan community tidak memiliki pengaruh terhadap peluang investasi atau pertumbuhan perusahaan. Hasil ini berbeda dengan penelitian Titisari et al (2010) dimana variabel environment, dan community memiliki pengaruh secara positif terhadap keputusan investor, namun employee berpengaruh negatif terhadap keputusan investasi. Hal ini berbanding terbalik dengan penelitian ini yang menunjukkan hanya employee yang memiliki pengaruh positif terhadap kondisi peluang investasi atau pertumbuhan perusahaan.

Ketidakpengaruhan secara parsial environment dan community terhadap Tobin's $Q$ dimungkinkan investor hanya membutuhkan informasi mengenai trend harga saham daripada faktor lingkungan atau komunitas eksternal tertentu yang berhubungan secara tidak langsung dengan perusahaan sebagai bahan pertimbangan. Hal ini menunjukkan perbedaan dengan ROA yang menunjukkan faktor community masih signifikan untuk dipertimbangkan sebagai keputusan yang berkaitan dengan profit. Faktor lingkungan tidak berpengaruh baik terhadap tingkat pengembalian dan pertumbuhan perusahaan. Hal ini berarti kurangnya perhatian investor terhadap aspek lingkungan sebagai pertimbangan jangka panjang.

\section{KESIMPULAN}

Kesimpulan mengenai pengaruh environment, employee, dan community terhadap ROA dan Tobin's $Q$ sebagai berikut:

1. Variabel-variabel CSR berpengaruh secara stimultan terhadap Return on Asset dan Tobin's $Q$ melalui Uji F

2. Variabel employee berpengaruh positif terhadap kondisi peluang investasi atau pertumbuhan perusahaan. Kemungkinan karena faktor tenaga kerja yang berhubungan langsung dengan operasional perusahaan menurut sudut pandang investor.

3. Variabel community tidak berpengaruh terhadap peluang investasi atau pertumbuhan perusahaan, sehingga dapat disimpulkan komunitas eksternal seperti pelanggan, serikat, atau masyarakat tidak terlalu berpengaruh dalam keputusan berinvestasi.

4. Variabel environment tidak berpengaruh baik terhadap tingkat pengembalian maupun peluang investasi atau kondisi pertumbuhan perusahaan. Hal ini mengindikasikan masih kurang sadarnya perusahaan-perusahaan di Indonesia dalam memperhatikan elemenelemen lingkungan dalam pengambilan keputusan yang berkaitan dengan keuntungan jangka panjang dan keputusan berinvestasi.

\section{DAFTAR PUSTAKA}

Biscaccianti, A. (2003). 'Bussines Ethics and Profit - The impact of corporate social responsibility programs on corporate strategic planning',CEREN, vol 5, no 1, hal.14-27.

Brammer, S, Brooks, C, \& Pavelin, S (2005).Corporate Social Performance and Stock Returns: UK Evidence from Disaggegate Measures, Financial Management. 
Brine, M, Brown, R, \& Hackett, G (2007).

Corporate social responsibility and financial performance in the Australian Context, Corporation and Financial Services Division, Australian Treasury.

Cooper, S \& Wagman, G (2009). Corporate Social Responsibility: A Study of Progression To The Next Level. Journal of Bussiness\& Economics Research, vol 7, no. 5, hal 97-102. [25 Juni 2011]

Fiori, G, Donato, F, \& Izzo, MF. (2007). Corporate social responsibility and firms performance, an analysis Italian listed companies.

Hadi, N. (2011).Corporate Social Responsibility. Graha Ilmu. Yogyakarta

Kasmir. (2008). Bank dan Lembaga Keuangan Lainnya. Edisi Revisi 2008. PT. Raja Grafindo Persada. Jakarta.

Kartajaya, H (2008). New Wave Marketing The World Is Still Round, The Market Is Already Flat. Gramedia Pustaka Utama. Jakarta.

Rachman, NM, Efendi, A, \& Wicaksana, E. (2011). Panduan Lengkap Perencanaan CSR. Penebar Swadaya. Jakarta.

Sayekti, Y dan Wondabio, L. (2007). Pengaruh CSR disclosure terhadap earning response coefficient (studi empiris pada perusahaan yang terdaftar di Bursa Efek Jakarta), Simposium Nasional Akuntansi $\mathrm{X}$

Titisari, KH, Eko, S, \& Doddy S. (2010). Corporate Social Responsibility (CSR) dan Kinerja Perusahaan. Simposium Nasional Akuntansi XIII, Purwokerto.

Velasquez, MG. (2002). Business Ethics, Concept and Cases $5^{\text {th }}$ Edition. Purwaningsih, A. Kurnianto, Budisantoso, T. (Penerjemah). Etika Bisnis, Konsep, dan Kasus, Edisi 5. Penerbit Andi. Yogyakarta. 